\title{
Evaluasi Surveilans Penyakit Tuberkulosis (TB) di RSPI Prof. Dr. Sulianti Saroso Tahun 2017
}

\author{
Evaluation of Tuberculosis (TB) Surveillance at Sulianti Saroso Infectious Disease \\ Hospital in 2017
}

Anita PD Nugroho*, Rosamarlina, Adria Rusli, Kunti Wijiarti, Bambang Setiaji

Rumah Sakit Penyakit Infeksi Prof. Dr. Sulianti Saroso

*Korespodensi Penulis:

Anita PD Nugroho

Email: nita.pdn@gmail.com

\begin{abstract}
Abstrak
Latar Belakang: Tuberkulosis (TB) merupakan penyakit menular langsung yang disebabkan M.tuberkulosis, menyerang semua usia melalui droplet orang yang telah terinfeksi. Di RSPI Sulianti Saroso terdapat tantangan berupa perbedaan output surveilans TB yaitu data akhir karena surveilans TB dilaksanakan di beberapa unit kerja. Tujuan: Mendapatkan gambaran pelaksanaan surveilans TB melalui evaluasi input, proses dan output sistem surveilans. Metode: Kualitatif desain studi evaluasi. Hasil: Surveilans TB tahun 2017 dilaksanakan Bidang Pengkajian Epidemiologi dan Pokja TB/MDR-TB. Hasil evaluasi input ada perbedaan definisi kasus pada tiap unit. Hasil evaluasi proses tidak ada diseminasi informasi. Hasil evaluasi output terdapat perbedaan pemenuhan indikator dan perbedaan cara perolehan data. Kesimpulan dan Saran: Terdapat dua unit yang melaksanakan surveilans TB yaitu Bidang Pengkajian Epidemiologi dan Pokja TB/MDR-TB, diperlukan peningkatan kapasitas SDM dan peningkatan kualitas data TB untuk pemenuhan indikator pelaporan.
\end{abstract}

Kata Kunci: Surveilans, TB

\begin{abstract}
Background: Tuberculosis (TB) is a directly-transmitted infectious disease caused by M. tuberculosis, which may infect people of all ages through droplets of infected people. At RSPI Sulianti Saroso, there were challenges in the form of differences in TB surveillance output, namely the final data because TB surveillance was carried out in several work units. This study aims to get an overview of the implementation of TB surveillance by evaluating the inputs, processes and outputs of the surveillance system. Method: This study employed a qualitative evaluation study design. Results: TB surveillance in 2017 was carried out by the Epidemiological Assessment Division and the TB/MDR-TB Working Group. The results of the input evaluation showed that there were differences in case definitions in each unit. The results of the process evaluation revealed that there was no dissemination of information. Meanwhile, the results of the evaluation of the output showed that there were differences in the fulfillment of indicators and differences in ways of obtaining data. Conclusions: There are two units that carry out TB surveillance, namely the Epidemiological Assessment Division and the TB/MDR-TB Working Group. It is necessary to increase human resource capacity and improve the quality of TB data to fulfill reporting indicators.
\end{abstract}

Keywords: Surveillance, TB 


\section{Pendahuluan}

Surveilans epidemiologi menurut World Health Organization (WHO) yaitu suatu proses pengumpulan, pengolahan, analisis dan interpretasi data kesehatan secara sistematis, terus menerus dan penyebarluasan informasi kepada pihak terkait untuk melakukan tindakan. ${ }^{(1)}$ Berdasarkan Keputusan Menteri Kesehatan (KMK) RI Nomor 1479/MENKES/SK/X/2003 tentang Pedoman Penyelenggaraan Sistem Surveilans Epidemiologi Penyakit Menular dan Penyakit Tidak Menular, dan Peraturan Menteri Kesehatan RI Nomor 949/MENKES/SK/VIII/2004 tentang Pedoman Penyelenggaraan SKD KLB bahwa rumah sakit merupakan salah satu unit pelayanan kesehatan yang wajib menyelenggarakan surveilans terpadu penyakit dan termasuk salah satu unit yang bertanggung jawab dalam SKD. ${ }^{(2)(3)}$ Peran rumah sakit disebutkan melakukan kajian epidemiologi ancaman KLB, memberikan peringatan kewaspadaan dini KLB dan peningatan kewaspadaan dan kesiapsiagaan terhadap KLB. Dalam pelaksanaan peran SKD tersebut, rumah sakit harus melakukan surveilans penyakit secara rutin dan terpadu. ${ }^{(2)}$

Berdasarkan Permenkes RI Nomor 45 Tahun 2014, penyelenggaraan surveilans kesehatan harus didukung dengan tersedianya: a. sumber daya manusia yang memiliki kompetensi di bidang epidemiologi; b. pendanaan yang memadai; dan c. sarana dan prasarana yang diperlukan termasuk pemanfaatan teknologi tepat guna.(2) Ketersediaan dukungan akan mendukung kelancaran proses dan output dari surveilans kesehatan.

RSPI Prof. Dr. Sulianti Saroso sebagai rumah sakit rujukan nasional penyakit infeksi dan menular, turut melaksanakan surveilans kesehatan dimana salah satunya adalah surveilans epidemiologi penyakit menular langsung. Berdasarkan tupoksi Seksi Pengendalian Penyakit Menular Langsung sesuai Permenkes no 247 tahun 2008 pasal 28 disebutkan RS: "Melakukan penyiapan bahan pengkajian dan evaluasi, serta pelaporan dibidang pengkajian pengendalian penyakit menular langsung."(4) Dalam melaksanakan tupoksinya seksi Pengendalian Penyakit Menular Langsung melakukan surveilans pada penyakit menular langsung (PML) yang berpotensi menimbulkan KLB/ Wabah sebagai upaya untuk mendukung program nasional, menghasilkan informasi sebagai kewaspadaan dini rumah sakit, perbaikan pelayanan, serta 
menghasilkan bahan kajian yang dapat dimanfaatkan baik internal maupun eksternal rumah sakit dan salah satu surveilans PML yang telah dilaksanakan oleh RSPI Prof. Dr. Sulianti Saroso adalah surveilans TB sesuai PMK No. 67 Tahun 2016 tentang Penanggulangan Tuberkulosis.

Pelaksanaan TB surveilans di RSPI Sulianti Saroso berbasis indikator dan surveilans berbasis kejadian. ${ }^{(5)}$ Surveilans ini dilaksanakan dengan menggunakan data layanan rutin yang dilakukan pada pasien TB. Sedangkan surveilans berbasis kejadian terdiri dari surveilans berbasis kejadian khusus melalui kegiatan survei periodik maupun sentinel dan surveilans berbasis KLB pada kasus TB lintas negara bagi warga negara Indonesia yang akan berangkat maupun yang akan kembali ke Indonesia (haji dan TKI). ${ }^{(6)}$ Selain itu surveilans TB Paru di RSPI Prof. Dr. Sulianti Saroso melibatkan beberapa unit diantaranya Pokja MDR TB melalui laporan online Sistem Informasi Tuberkulosis Terpadu (SITT) dan e-TB Manager, Bidang Pengkajian Epidemiologi melalui laporan rutin bulanan Surveilans Terpadu Penyakit Rumah Sakit (STP RS) ke Dinkes DKI Jakarta dan Instalasi Rekam Medik melalui laporan kunjungan pasien TB ke Direktur Utama.
Surveilans TB di RSPI Prof. Dr. Sulianti Saroso memiliki berbagai tantangan, antara lain belum adanya integrasi data antar unit pelaksana surveilans TB Paru yang mengakibatkan terjadinya perbedaan data TB yang dilaporkan antar unit pelapor; pemantauan kasus TB belum berjalan dengan baik disebabkan belum terpenuhinya tenggat waktu rekap data kasus di Instalasi Rekam Medik dan belum berjalannya sistem koding kasus baru pada pasien lama, belum adanya verifikator input data untuk memastikan setiap data yang masuk sudah valid dan tepat waktu dan belum berjalannya surveilans faktor risiko TB karena kurangnya dukungan data. Berdasarkan gambaran diatas maka diperlukan suatu kajian yang dapat mengevaluasi pelaksanaan surveilans TB di RSPI Sulianti Saroso dengan judul "Pemetaan dan Evaluasi Surveilans Penyakit Menular Langsung Tuberkulosisi (TB) di RSPI Prof. Dr. Sulianti Saroso Tahun 2017".

\section{Metode}

Desain kajian ini yaitu studi evaluasi dengan pendekatan kualitatif. Sampel dalam penelitian ini informan terpilih untuk wawancara mendalam. Sumber data menggunakan data primer dan data sekunder. Analisa data secara deskriptif. 
Tabel 1. Input Sistem Surveilans TB Paru Tahun 2017

\begin{tabular}{|c|c|c|c|c|c|c|c|c|c|}
\hline & \multirow{3}{*}{ Evaluasi } & \multicolumn{8}{|c|}{ Surveilans TB Paru } \\
\hline & & \multicolumn{2}{|c|}{$\begin{array}{c}\text { Bidang } \\
\text { Epidemiologi }\end{array}$} & \multicolumn{2}{|c|}{$\begin{array}{l}\text { Pokja TB/ } \\
\text { MDR-TB }\end{array}$} & \multicolumn{2}{|c|}{$\begin{array}{c}\text { Instalasi } \\
\text { Rekam Medik }\end{array}$} & \multicolumn{2}{|c|}{$\begin{array}{c}\text { Unit lain } \\
\text { (Laboratorium) }\end{array}$} \\
\hline & & Ada & $\begin{array}{c}\text { Tidak } \\
\text { ada }\end{array}$ & Ada & $\begin{array}{c}\text { Tidak } \\
\text { ada }\end{array}$ & Ada & $\begin{array}{c}\text { Tidak } \\
\text { ada }\end{array}$ & Ada & $\begin{array}{l}\text { Tidak } \\
\text { ada }\end{array}$ \\
\hline \multirow[t]{2}{*}{1} & Man - SDM surveilans & $\mathrm{v}$ & & & $\mathrm{v}$ & & $\mathrm{v}$ & & $\mathrm{v}$ \\
\hline & SDM lab & & v & & v & & v & & v \\
\hline 2 & Money (Anggaran) & v & & & $\mathrm{v}$ & & $\mathrm{v}$ & & $\mathrm{v}$ \\
\hline \multirow[t]{4}{*}{3} & Metode & & & & & & & & \\
\hline & - pedoman & V & & $\mathrm{v}$ & & & $\mathrm{v}$ & & V \\
\hline & - kebijakan/ payung hukum & v & & v & & $\mathrm{V}$ & & v & \\
\hline & - definisi kasus & $\mathrm{v}$ & & $\mathrm{v}$ & & $\mathrm{v}$ & & v & \\
\hline \multirow[t]{6}{*}{4} & Material-Machine & & & & & & & & \\
\hline & - APD & & v & & $\mathrm{V}$ & & $\mathrm{V}$ & & v \\
\hline & - Alat komunikasi & $\mathrm{v}$ & & $\mathrm{v}$ & & v & & v & \\
\hline & - Formulir surveilans & v & & $\mathrm{v}$ & & & $\mathrm{v}$ & $\mathrm{v}$ & \\
\hline & - Komputer & $\mathrm{V}$ & & $\mathrm{v}$ & & $\mathrm{v}$ & & v & \\
\hline & - Aplikasi surveilans & & v & $\mathrm{v}$ & & & $\mathrm{v}$ & $\mathrm{v}$ & \\
\hline \multirow[t]{3}{*}{5} & Market & & & & & & & & \\
\hline & - pengguna internal & & v & v & & v & & v & $\mathrm{v}$ \\
\hline & - pengguna eksternal & $\mathrm{v}$ & & $\mathrm{v}$ & & & $\mathrm{v}$ & $\mathrm{v}$ & \\
\hline
\end{tabular}

Evaluasi input sistem surveilans meliputi penilaian terhadap Man yaitu SDM Surveilans dan SDM Laboratorium, Money (anggaran) yaitu anggaran untuk mendukung kegiatan, Metode berupa acuan pelaksanaan dalam bentuk pedoman, kebijakan dan definisi kasus, Material yaitu sarana dan prasarana pendukung pelaksanaan surveilans TB dan Market yaitu sasaran penyebaran informasi surveilans baik internal maupun eksternal.

Pada Tabel 1 diatas terdapat 4 (empat) unit yang terlibat dalam input sistem surveilans yaitu Bidang
Pengkajian Epidemiologi, Pokja TB/MDR-TB, Instalasi Rekan Medik dan Laboratorium.

Proses dalam sistem surveilans meliputi pengumpulan data, pengolahan data, analisis dan interpretasi data, serta diseminasi informasi. Dari evaluasi terhadap 4 unit, hanya 1 unit yang dapat menunjukkan proses kegiatan surveilans yaitu Bidang Pengkajian Epidemiologi (Tabel 2) 


\section{Proses}

Tabel 2. Proses Sistem Surveilans TB Paru Tahun 2017

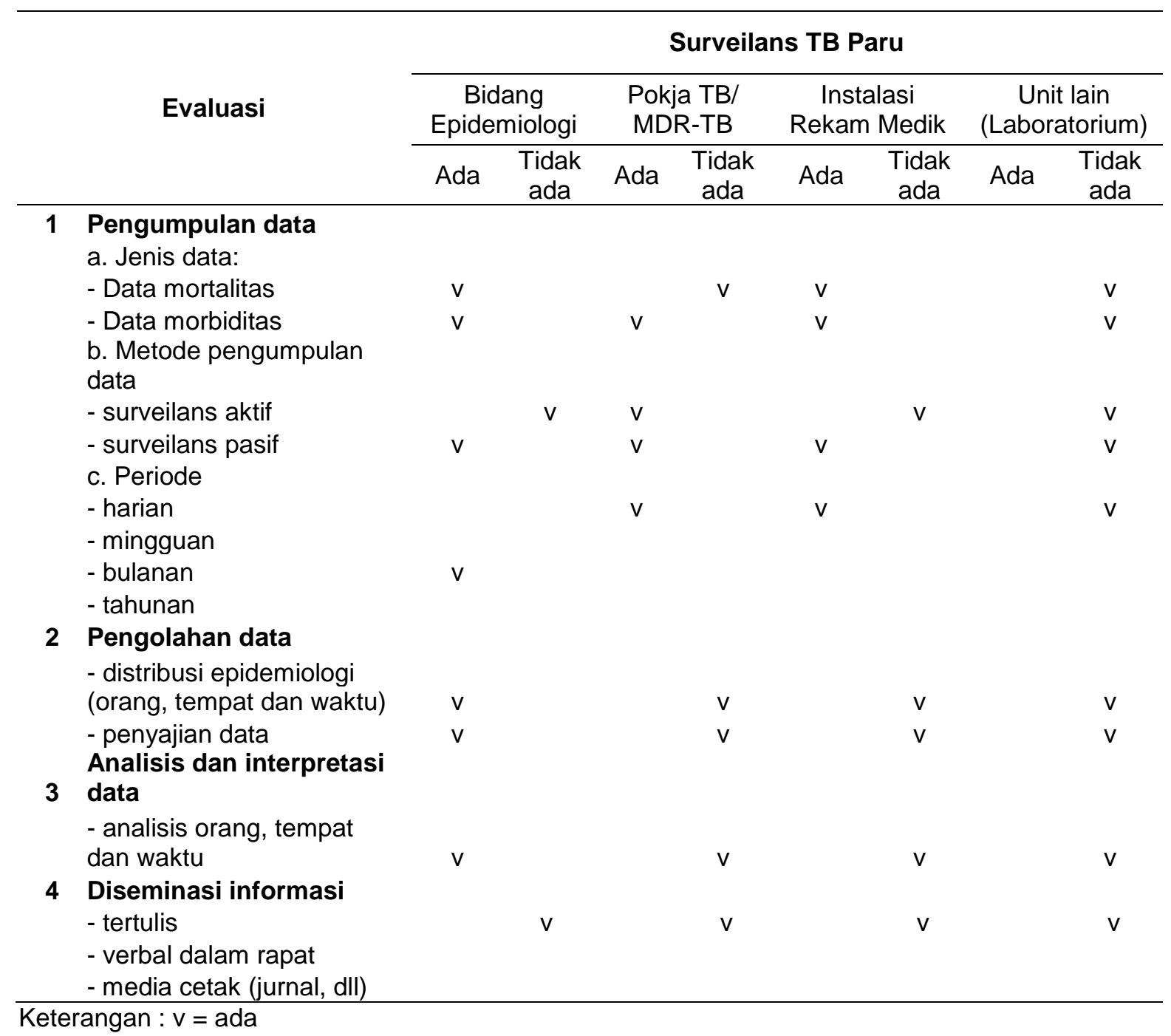

\section{Output}

Tabel 3. Output Sistem Surveilans TB Paru Tahun 2017

\begin{tabular}{|c|c|c|c|c|c|c|c|c|c|}
\hline & \multirow{3}{*}{ Evaluasi } & \multicolumn{8}{|c|}{ Surveilans TB Paru } \\
\hline & & \multicolumn{2}{|c|}{$\begin{array}{c}\text { Bidang } \\
\text { Epidemiologi }\end{array}$} & \multicolumn{2}{|c|}{$\begin{array}{l}\text { Pokja TB/ } \\
\text { MDR-TB }\end{array}$} & \multicolumn{2}{|c|}{$\begin{array}{c}\text { Instalasi } \\
\text { Rekam Medik }\end{array}$} & \multicolumn{2}{|c|}{$\begin{array}{c}\text { Unit lain } \\
\text { (Laboratorium) }\end{array}$} \\
\hline & & Ada & $\begin{array}{l}\text { Tidak } \\
\text { ada }\end{array}$ & Ada & $\begin{array}{l}\text { Tidak } \\
\text { ada }\end{array}$ & Ada & $\begin{array}{l}\text { Tidak } \\
\text { ada }\end{array}$ & Ada & $\begin{array}{l}\text { Tidak } \\
\text { ada }\end{array}$ \\
\hline \multirow[t]{3}{*}{$\begin{array}{l}1 \\
2\end{array}$} & $\begin{array}{l}\text { Laporan surveilans internal } \\
\text { Laporan surveilans }\end{array}$ & & v & $v$ & & $v$ & & & $\mathrm{v}$ \\
\hline & eksternal & $\mathrm{v}$ & & $\mathrm{v}$ & & & $\mathrm{v}$ & & $\mathrm{v}$ \\
\hline & $\begin{array}{l}\text { Informasi kasus/ distribusi } \\
\text { penyakit menurut orang, } \\
\text { tempat dan waktu }\end{array}$ & & $\mathrm{v}$ & & $\mathrm{v}$ & & $\mathrm{v}$ & & $\mathrm{v}$ \\
\hline
\end{tabular}

Keterangan $: \mathrm{v}=$ ada 
Evaluasi output sistem surveilans berupa laporan internal dan eksternal dan informasi kasus yang telah didistribusi menurut orang, tempat dan waktu. Pada ke-4 unit yang dievaluasi terdapat 3 unit kerja yang memiliki output sistem surveilans yaitu Bidang Pengkajian Epidemiologi, Pokja TB/MDR-TB dan Instalasi Rekam Medik.

\section{Pembahasan}

Input

SDM Bidang Pengkajian Epidemiologi memiliki petugas khusus surveilans dengan kompetensi di bidang epidemiologi berlatar belakang pendidikan S1 dan S2 epidemiologi.

Pokja TB/MDR-TB tidak memiliki petugas khusus surveilans TB, namun memiliki satu orang petugas berlatar belakang perawat yang bertugas sebagai pelaksana pencatatan dan pelaporan TB ke dalam aplikasi surveilans TB sekaligus membantu administrasi pasien.

Instalasi Rekam Medik (IRM) juga tidak memiliki petugas khusus surveilans TB, SDM di Instalasi Rekam Medik umumnya adalah perekam medik yang betugas untuk melakukan coding, filling, assembling dan tugas perekam medik lainnya.
Di dalam SK Tim Kelompok Kerja TB dan MDR TB RSPI Sulianti Saroso Tahun 2018 tercantum satu orang anggota kelompok kerja yang berasal dari laboratorium sebagai seksi penunjang pelaksanaan kegiatan laboratorium TB/MDR-TB, namun dalam pelaksanaannya kegiatan laboratorium untuk TB/MDR-TB adalah seluruh petugas/ analis kesehatan di bagian mikrobiologi laboratorium. ${ }^{(7)}$

Acuan kegiatan surveilans TB pada setiap unit pelaksana berbeda-beda, sehingga definisi kasus juga berbeda. Definisi kasus TB pada Bidang Pengkajian Epidemiologi masih mengacu pada PMK 1479 Tahun 2003 yaitu pemeriksaan sputum BTA dan pengumpulan datanya pada seluruh kasus suspek dan konfirmasi pada rawat jalan dan rawat inap, sedangkan definisi kasus TB di Pokja TB/MDR-TB saat ini telah mengikuti kebijakan terbaru PMK No. 67 Tahun 2016 tentang Penanggulangan Tuberkulosis yaitu pasien TB yang pada hasil pemeriksaan mikroskopis langsung, TCM TB atau biakan terbukti positif, dan pasien TB yang terdiagnosis secara klinis TB dan pengumpulan datanya hanya pada pasien yang memperoleh pengobatan di Pokja $\mathrm{Tb} / \mathrm{TB}-M D R$ saja. Hingga saat kajian dilakukan, surveilans TB di Bidang 
Pengkajian Epidemiologi masih mengacu pada PMK 1479 Tahun 2003. ${ }^{(8)(9)}$

IRM tidak memiliki definisi kasus TB, penginputan kasus TB di IRM mengikuti diagnosa yang dituliskan dokter dalam berkas rekam medis pasien rawat jalan dan rawat inap sedangkan Instalasi Laboratorium hanya melalukan pemeriksaan sesuai standar kompetensi.

Perbedaan yang terjadi adalah perbedaan hasil penghitungan jumlah kasus di Bidang Pengkajian Epidemiologi dan Pokja TB/MDR-TB/ Penghitungan jumlah kasus TB di Bidang Pengkajian Epidemiologi dilihat berdasarkan rekap jumlah kasus baru yang didiagnosis TB di RSPI Sulianti Saroso. yang berasal dari Instalasi Rekam Medik bersumber dari unit layanan, baik rawat inap maupun rawat jalan maupun yang datang ke Pokja TB/MDR-TB, sedangkan Pokja TB/MDR-TB, penghitungan jumlah kasus TB berdasarkan jumlah kasus baru yang datang ke Pokja tersebut saja.

Secara umum tersedia alat komunikasi, komputer dan formulir surveilans. Formulir surveilans TB yang tersedia di Pokja TB/MDR-TB yaitu formulir TB 01-13, sedangkan di Bidang Pengkajian Epidemiologi tersedia formulir Surveilans Terpadu Penyakit
(STP RS). Untuk Instalasi Rekam Medik tidak memiliki formulir surveilans TB dan untuk Instalasi Laboratorium tersedia formulir hasil pemeriksaan TB yang terintegrasi dengan formulir TB di Pokja TB/MDR-TB.

Untuk aplikasi surveilans TB, hanya tersedia di Pokja TB/MDR-TB berupa aplikasi Sistem Informasi Tuberkulosis Terpadu (SITT) untuk pelaporan TB sensitif dan e-TB Manager untuk pelaporan TB RO. Aplikasi SITT di Pokja TB/MDR-TB terhubung dengan aplikasi SITT di Instalasi Laboratorium.

Variabel data yang ada dalam SITT dan e-TB Manager cukup banyak dan variatif dari pada variabel yang ada di SIM RSPI Sulianti Saroso, diharapkan aplikasi ini dapat terintegrasi ke SIM RSPI Sulianti Saroso sehingga dapat memperkaya data surveilans TB dan juga sebagai back up data apabila terjadi gangguan server aplikasi SITT dan e-TB Manager.

Acuan pelaksanaan surveilans TB seharusnya telah mengikuti standar terbaru yaitu terbaru PMK No. 67 Tahun 2016 tentang Penanggulangan Tuberkulosis yang diadopsi oleh Pokja TB/MDR, mengingat material dan machine di Pokja TB/MDR-TB cukup lengkap dan terkini, pelaksanaan surveilans TB dapat dilaksanakan di Pokja TB/MDR-TB saja dengan 
mengakomodir baik data rawat jalan maupun rawat inap.

Unit pelaksana surveilans TB yang memiliki sasaran penyebaran informasi adalah Bidang Pengkajian Epidemiologi dan Pokja TB/MDR-TB. Sasaran hasil surveilans TB di Bidang Pengkajian Epidemiologi adalah Dinas Kesehatan DKI Jakarta, sedangkan sasaran hasil surveilans Pokja TB/MDR-TB adalah Kementerian Kesehatan, Dinas Kesehatan DKI Jakarta, Sudinkes Jakarta Utara serta internal RSPI Sulianti Saroso. Terjadi dua unit pelaksana surveilans dengan sasaran penyebaran informasi yang berbeda karena kedua-duanya memang melaksanakan surveilans sesuai dengan tugas dan fungsinya. Pelaksanaan surveilans dilakukan di Bidang Pengkajian Epidemiologi dari tahun 2008 dimana tugas dan fungsi surveilans merupakan bagian dari Struktur Organisasi dan Tata Kerja (SOTK) Rumah Sakit berdasarkan Permenkes No 247 tahun 2008 dan RSPI Sulianti Saroso merupakan satusatunya rumah sakit di Indonesia yang memiliki tugas dan fungsi surveilans penyakit infeksi dan penyakit menular. Dari awal pembentukan sasaran penyebaran informasi adalah Dinas Kesehatan sesuai dengan acuan payung hukum surveilans TB yang diadopsi Bidang Pengkajian Epidemiologi. Sedangkan Pokja TB/MDR-TB dibentuk oleh rumah sakit pada tahun 2016 berdasarkan Surat Keputusan Direktur Utama dengan tujuan untuk mendukung pengendalian TB yang menjadi salah satu program utama pemerintah saat itu dengan sasaran penyebaran informasi adalah sesuai dengan acuan payung hukum surveilans TB.

\section{Proses}

Jenis data TB yang dikumpulkan oleh Bidang Pengkajian Epidemiologi adalah data morbiditas dan mortalitas. Periode pengambilan data adalah bulanan, metode pengumpulan data adalah pasif dengan sumber data berasal dari rekap data dalam aplikasi SIM RS yang berasal dari rekam medik pasien. ${ }^{(10)}$

Jenis data yang dikumpulkan oleh Pokja TB/MDR-TB adalah data morbiditas yang sesuai pada formulir rekam medik dan formulir TB 01-TB13. Periode pengumpulan data adalah harian, metode pengumpulan data aktif dan pasif. Data pasien dihitung berdasarkan kasus baru TB/MDR-TB yang memperoleh pelayanan di Pokja TB/MDR-TB.

Jenis data yang dikumpulkan oleh Instalasi Rekam medik adalah data jumlah kunjungan pasien atau data 
agregat. Periode pengumpulan data adalah bulanan, triwulan, semester dan tahunan. Metode pengumpulan data adalah pasif.

Pengumpulan data di Bidang Pengkajian Epidemiologi bergantung pada hasil rekap data bulanan yang diambil dari aplikasi SIM RS yang merupakan serapan data dari seluruh unit layanan yang telah dikoding akhir di Instalasi Rekam Medik. Rekap data bulanan TB di aplikasi SIM RS sangat dipengaruhi oleh ketepatan waktu koder dalam menginput data diagnosa utama akhir ke dalam aplikasi.

Berdasarkan penelusuran sumber terdapat informasi bahwa kepentingan klaim Jaminan Kesehatan Nasional (JKN) dan persepsi koder juga dapat mempengaruhi kevalidan jumlah akhir data yang dilaporkan oleh Bidang Pengkajian Epidemiologi. Data TB yang ada dalam aplikasi SIM RS merupakan hasil input data diagnosa utama akhir dari koder Instalasi Rekam Medik dan koder Instalasi JKN. Dimana koding data yang dilakukan di Instalasi Rekam Medik dapat berubah di Instalasi JKN karena penyesuaian klaim JKN/BPJS. Diharapkan dapat dilakukan kajian lanjutan untuk melihat sejauh mana perbedaan data sebelum dan sesudah penyesuaian klaim JKN/BPJS terhadap hasil akhir rekap data surveilans.
Unit surveilans TB yang melaksanakan pengolahan data adalah Bidang Pengkajian Epidemiologi. Bidang Pengkajian Epidemiologi telah melakukan pengolahan data secara deskriptif berdasarkan orang, tempat dan waktu. Unit surveilans TB yang melaksanakan analisis dan interpretasi data adalah Bidang Pengkajian Epidemiologi. Analisis data surveilans TB masih univariat berdasarkan pola penyakit secara epidemiologi berdasarkan orang, tempat dan waktu. Variabel orang dikumpulkan untuk melihat karakteristik penyakit TB seperti dilihat dalam umur dan jenis kelamin, variabel tempat untuk melihat kewaspadaan dini penyakit TB seperti wilayah tempat tinggal, sedangkan variabel waktu meliputi hari, minggu, bulan, tahun, musim, dan lain-lain bertujuan untuk melihat kecenderungan kasus TB. Secara keseluruhan analisis data TB di RSPI Sulianti Saroso banyak dimanfaatkan untuk mendukung penelitian di rumah sakit, selain itu untuk melihat kecenderungan kasus, sebagai sistem kewaspadaan dini, dan evaluasi program layanan.

Tahun 2017, diseminasi informasi belum berjalan maksimal sekalipun proses sistem surveilans sudah berjalan di Bidang Pengkajian Epidemiologi dan Pokja TB/MDR-TB, demikian juga untuk tahun-tahun 
sebelumnya, hal tersebut disebabkan masih lemahnya pendokumentasian kegiatan diseminasi informasi hasil surveilans TB.

\section{Output}

$\begin{array}{rcc}\text { Output } & \text { surveilans } & \text { Bidang } \\ \text { Pengkajian } & \text { Epidemiologi } & \text { adalah }\end{array}$ laporan TB dan Suspek TB pada formulir Surveilans Terpadu Penyakit Rumah Sakit (STP-RS) yang dikirimkan melalui email ke Dinas Kesehatan DKI Jakarta setiap awal bulan sebelum tanggal 10. Output surveilans TB pada Pokja TB/MDR-TB adalah laporan online melalui aplikasi e-TB Manager untuk kasus MDR TB setiap hari dan aplikasi SITT untuk TB sensitif setiap bulan. Untuk Instalasi Rekam Medik, tidak disebutkan sebagai laporan surveilans TB tetapi laporan kunjungan pasien TB yang dilaporkan setiap bulan berupa data agregat atau rekapan akhir sebagai salah satu Indikator Kinerja Individu Direktur Utama (IKI Dirut).

Pemenuhan indikator ketepatan waktu pelaporan surveilans TB dalam tahun 2017 (12 bulan) di Bidang Pengkajian Epidemiologi yaitu sebesar 66,7 , sedangkan kelengkapan laporan sebesar 33,3 \%. Tidak terpenuhinya indikator pelaporan $100 \%$ di Bidang Pengkajian Epidemiologi adalah karena rekap data yang diperoleh dari aplikasi SIM RS sangat bergantung pada ketepatan waktu penginputan data dan kepatuhan pengisian data secara lengkap oleh penginput data akhir di IRM dan JPK.

Untuk Pokja TB/MDR-TB ketepatan dan kelengkapan pelaporan surveilans TB terpenuhi $100 \%$. Indikator terpenuhi karena petugas dapat menginput langsung data pasien secara real time ke dalam system. Namun seiring dengan bertambahnya jumlah pasien di Pokja TB/MDR-TB, pemenuhan indikator tersebut harus tetap dipertahankan dan memerlukan perhatian apakah SDM surveilans yang bertugas rangkap masih mampu atau tidak dalam memenuhi indikator tersebut.

\section{Kesimpulan}

1. Rangkaian pelaksanaan surveilans TB di RSPI Sulianti Saroso dilaksanakan oleh dua unit kerja yaitu Bidang Pengkajian Epidemiologi dan Pokja TB/MDR-TB sedangkan unit lain adalah untuk mendukung ketersediaan data surveilans TB adalah Instalasi Rekam Medik dan Instalasi Laboratorium.

2. Berdasarkan evaluasi input surveilans; hanya Bidang Pengkajian Epidemiologi yang memiliki SDM khusus surveilans, perbedaan fungsi dan definisi kasus surveilans TB 
antara Bidang Pengkajian

Epidemiologi dengan Pokja

TB/MDR-TB karena perbedaan acuan pedoman (kebijakan/payung hukum).

3. Berdasarkan evaluasi proses surveilans, rangkaian proses surveilans dari pengumpulan data hingga analisis dan interpretasi data dilaksanakan oleh Bidang Pengkajian Epidemiologi.

4. Berdasarkan evaluasi output surveilans; capaian indikator surveilans Bidang Pengkajian Epidemiologi tidak tercapai karena dipengaruhi oleh ketepatan waktu dan kelengkapan data oleh penginput data akhir di IRM dan JPK.

\section{Saran}

1. Peningkatan kualitas data TB dalam aplikasi SIM RS untuk mendukung ketersediaan data yang lengkap dan tepat waktu

2. Penguatan dan peningkatan kompetensi SDM surveilans agar hasil surveilans dapat dimanfaatkan untuk peningkatan pelayanan, penelitian dan sebagai dasar evaluasi program penanggulangan TB

3. Peningkatan kualitas data TB dapat berupa integrasi aplikasi data TB dengan SIM RSPI Sulianti Saroso dan pelaksanaan surveilans TB satu pintu di Pokja TB/MDR-TB.

\section{Daftar Pustaka}

1. Lapau B, Birwin A. Prinsip dan metode epidemiologi. In: Prinsip dan metode epidemiologi. 2017.

2. Peraturan Menteri Kesehatan RI PMK. No 45 Tahun 2014. tentang penyelenggaraan Surveilans Kesehat. 2014;19(1):27-40.

3. Peraturan Menteri Kesehatan RI RI No 949 Tahun 2004 tentang Pedoman Penyelenggaraan Sistem Kewaspadaan Dini (SKD) Kejadian Luar Biasa (KLB).2004;

4. Kementrian Kesehatan RI. Peraturan Menteri Kesehatan No 247/MENKES/PER/III/2008. tentang Organisasi dan Tata Kerja RS Prof Dr Sulianti Saroso. 2008;

5. Permenkes. No 67 Tahun 2016. Penanggulangan Tuberkulosis. 2016;

6. Direktorat Jenderal Pengendalian Penyakit dan Penyehatan Lingkungan. Modul 3 Dasar-Dasar Surveilans Epidemiologi. Jakarta: Departemen Kesehatan RI; 2009.

7. Amiruddin R. Surveilans Kesehatan Masyarakat. IPB Press. 2012;

8. Menteri Kesehatan. Keputusan Menteri Kesehatan Republik Indonesia No 1479/MENKES/SK/ $\mathrm{X} / 2003$ tentang pedoman 
penyelenggaraan sistem surveilans epidemiologi penyakit menular dan penyakit tidak menular terpadu. 2003;

9. Novanty F, Ningrum DNA. Evaluasi Input Sistem Surveilans Penemuan Suspek Tuberkulosis (Tb) Di Puskesmas Wilayah Kerja Dinas Kesehatan Kabupaten Magelang. unnes j public heal. 2016;

10.Arina Mufida Ersanti, Agung Nugroho ACH. Gambaran Kualitas Sistem Surveilans TB di Dinas Kesehatan Kabupaten Gresik Berdasarkan Pendekatan Sistem dan penilaian Atribut. J Inf Syst Public Heal. 2017; 